ISLAMIC BANKING: Jurnal Pemikiran dan Pengembangan Perbankan Syariah, Volume 7 Nomor 1 Edisi Agustus 2021

\title{
DAMPAK COVID 19 TERHADAP SISTEM PEMBELAJARAN DAN KEUANGAN DI STEBIS IGM
}

\author{
Fadilla \\ Sekolah Tinggi Ekonomi dan Bisnis Syariah (STEBIS) Indo Global Mandiri \\ Email: fadilla@ stebisigm.ac.id \\ Meika Puspita Sari \\ Universitas Muhammadiyah Palembang \\ Email: meikapuspitasari@gmail.ac.id
}

\begin{abstract}
This research was conducted at STEBI IGM Palembang. Covid 19 causes STEBIS IGM students to be unable to pay UKT (Single Tuition Fee) on time because many parents of students have lost their jobs and students who are working have also been unable to pay UKT because they have been laid off. $30 \%$ of STEBIS IGM students cannot pay UKT. To activate it, STEBIS IGM provides an opportunity for 2 (two) UKT payments for students who can't afford it. Covid 19 caused learning at STEBIS IGM to also change from offline (face to face) to online (online). To facilitate online learning, STEBIS IGM has been assisted by using the online academic system, namely SIAKAD and Edlink. Lecturers can send materials, assignments and even conduct teleconferences through this edlink system. There are several obstacles in the online learning system 1) Unstable network. 2) Lecturers find it difficult to monitor their students one by one, 3) Students are reluctant to follow the zoom given the lack of time to ask questions and learn 4) Practical courses are difficult to explain if not face-to-face
\end{abstract}

Keywords: Covid 19, Learning System, Finance

\begin{abstract}
Abstrak
Penelitian ini dilakukan di STEBI IGM Palembang. Covid 19 menyebabkan mahasiswa STEBIS IGM tidak dapat membayar UKT (Uang Kuliah Tunggal) secara tepat waktu karena banyak orang tua dari mahasiswa kehilangan pekerjaannya dan mahasiswa yang bekerja juga telah tidak dapat membayar UKT karena telah dirumahkan. 30 \% mahasiswa STEBIS IGM tidak dapat membayar UKT. Untuk mengaktisipasinya maka STEBIS IGM memberikan kesempatan sebanyak 2 (dua) kali pembayaran UKT bagi mahasiswa yang tidak mampu. Covid 19 menyebabkan pembelajaran di STEBIS IGM juga berubah dari Luring (tatap muka) menjadi Daring (online). Untuk memperlancar pembelajaran secara daring STEBIS IGM telah dibantu dengan menggunakan sistem akademik secara online yaitu SIAKAD dan Edlink. Dosen dapat mengirimkan materi, tugas bahkan melakukan teleconference melalui sistem edlink ini. Ada beberapa hambatan dalam sistem pembelajaran secara online 1)Jaringan yang tidak stabil 2)Dosen sulit memonitor mahasiswanya satu persatu, 3)Mahasiswa menjadi segan mengikuti zoom mengingat sedikitnya waktu buat bertanya dan belajar 4)Mata Kuliah praktikum sulit dijelaskan jika tidak melalui tatap muka
\end{abstract}

Kata Kunci: Covid 19, Sistem Pembelajaran, Keuangan 
96 | Fadilla, Meika Puspita Sari, DAMPAK COVID 19 TERHADAP SISTEM PEMBELAJARAN ......

\section{Dasar Pemikiran}

Pada akhir tahun 2019 dunia telah digunacangkan dengan sebuah virus yang membuat banyak perubahan bagi kehidupan masyarakat dunia secara keseluruhan virus ini dikenal dengan Covid 19. Virus Corona (Corona Virus Diseases) adalah keluarga besar virus yang menyebabkan penyakit ringan sampai berat, seperti common cold atau pilek dan penyakit yang serius seperti MERS dan SARS. (Noer, dkk, 2020 : 61) Penyebarannya Virus ini sangat cepat sehhingga jika kita tidak waspada dan hati-hati dan bagi orang yang tubuhnya lemah. Jika kita tidak menjaga kesehatan tubuh kita virus ini dapat mengakibatkan kematian.

Sumber penularan kasus virus ini sampau sekarang belum diketahui secara pasti, namun kasus pertama kali penyebaran covid 19 ini dikaitkan dengan pasar ikan di Wuhan, Cina. Tanggal 18 desember hingga 29 desember 2019 virus ini telah menular ke seluruh daerah yang ada disekitarnya, sejak 31 desember 2019 hingga 3 januari 2020 kasus penularan vuris ini telah menigkat dengan pesat, ditandai dengan bertambah kasus virus COVID19 menjadi 44 kasus. Bahkan tidak sampai satu bulan virus ini telah menyebar ke negara yang lain seperti, Thailand, Jepang dan Korea Selatan (south korea). Di Indonesia pertama kali pada tanggal 2 maret 2020. Sejumlah 2 kasus, lalu ditanggal 21 maret 2020 terkonfirmasi berjumlah 1.528 kasus dan 136 kasus kematian, di asia tenggara Indonesia yang palin penyebarannya dan kematiannya. (Tobing, 2020 : 615)

Hingga saat ini jumlah kasus masyarakat yang positif terkena virus Covid 19 meningkat secara signifikan. Tercatat hingga tanggal 19 April jumlah kasus positif Covid 19 di Indonesia berjumlah 6.575 orang dan yang sembuh 686 orang sementara yang meninggal dunia berjumlah 582 orang (Kompas, 2020). Pada tanggal 20 Mei 2020, jumlah ini meningkat drastis menjadi 19.189 kasus positif, sementara yang sembuh berjumlah 4.575 orang dan yang meninggal sebanyak 1.242 orang (Nugraheny, 2020). Jika dikalkulasikan sejak pertama kali penyebaran virus 2019 tanggal 2 Maret 2020 dalam waktu sekitar 2,5 bulan ada penambahan sekitar 19.187 orang.

Dampak Covid 19 meliputi beberapa aspek kehidupan mulai dari sosial, ekonomi, juga dalam dunia pendidikan. Untuk menghindari Covid 19 pemerintah 
ISLAMIC BANKING: Jurnal Pemikiran dan Pengembangan Perbankan Syariah, Volume 7 Nomor 1 Edisi Agustus 2021

menerapkan Pembatasan Sosial Berskala Besar (PSBB), masyarakat diwajibkan menggunakan masker ketika keluar rumah, juga menjaga jarak minimal 1 Meter serta selalu mencuci tangan dan membawa handsaitizer.

Semenjak merebaknya Covid 19 perekonomian seluruh dunia melumpuh termasuk di Indonesia. Banyak perusahaan yang terpaksa gulung tikar karena tidak sanggup membayar gaji karyawan sehingga banyak pekerja yang dirumahkan dan kehilangan pekerjaan. Sistem pembelajaran juga mengalami perubahan yang semuala online dimana guru/dosen bisa memberikan pembelajaran secara tatap muka sekarang pembelajaran dilakukan secara onlie (Daring).

Sekolah Tinggi Ekonomi dan Bisnis Syariah (STEBIS IGM) Indo Global Mandiri merupakan salah satu contoh dari Universitas yang mengalami dampak dari Covid 19. Covid 19 telah menyebabkan banyaknya orang tua dari para mahasiswa STEBIS IGM kehilangan pekerjaannya serta menyebabkan usaha dari orang tua mengalami kebangkrutan. Akibatnya mahasiswa telat melakukan pembayaran Uang Kuliah Tunggal (UKT)/SPP. Pembayaran Berikut ini merupakan data dari beberapa mahasiswa STEBIS IGM yang tterlambat mengisis KRS dikarenakan belum melunasi pembayaran UKT

Tabel 1.1.

Data Mahasiswa STEBIS IGM yang terlambat Pembayaran UKT

\begin{tabular}{|c|l|l|}
\hline No & NPM & Nama Mahasiswa \\
\hline 1 & 201801063 & M. Reza Fahlefi \\
\hline 2 & 201801069 & Meinur Aulia \\
\hline 3 & 201801070 & Meliari Ramadhon \\
\hline 4 & $201801160 P$ & Yayan \\
\hline 5 & $201801162 P$ & Muhammad Fathul Barie \\
\hline 6 & 201801176 & Jhoty Rizky Midia \\
\hline 7 & 201901047 & Dandy Pratama \\
\hline 8 & 201901078 & Jhodi Alpayed \\
\hline 9 & $201901084 P$ & Sakroni \\
\hline 10 & 202001048 & Herli \\
\hline 11 & 202001049 & Muhammad Iqbal \\
\hline 12 & 201802025 & Fitriani \\
\hline 13 & 201902021 & Ernita \\
\hline 14 & 201902022 & Kintan Nurul Adiffah \\
\hline 15 & 202002016 & Diansari \\
\hline
\end{tabular}


98 Fadilla, Meika Puspita Sari, DAMPAK COVID 19 TERHADAP SISTEM PEMBELAJARAN ......

\begin{tabular}{|c|c|c|}
\hline 16 & 201801058 & M. Alamsyah Harahap \\
\hline 17 & 201701021 & Memi Martalia \\
\hline 18 & 201701006 & Despa Leni \\
\hline 19 & 201701034 & Shinta Tri Lestari \\
\hline 20 & 201701036 & Slamet Abdul Aziz \\
\hline 21 & 201701040 & Wina Windari \\
\hline 22 & 201801115 & Siti Fatimah \\
\hline 23 & 201801123 & Suryani \\
\hline 24 & 201801173 & Rachmat Hastono Putra \\
\hline 25 & 201901068 & Satria Anugrah \\
\hline 26 & 201901070 & Mira Afriyanti \\
\hline 27 & 202001019P & M. Al Kausar \\
\hline 28 & 202001038 & Rahayu Widodo \\
\hline 29 & 202001039 & Kgs. M. Abdus Samad Al Palembani \\
\hline 30 & 202001040 & M. Malik Fajar \\
\hline 31 & 202001056 & Nesya Salma Waafi \\
\hline 32 & 201702008 & Dwi Septi Ningsih \\
\hline 33 & 201802041 & Mutiara \\
\hline 34 & 202002019 & Ade Restamia Putri \\
\hline 35 & 201701012 & Eriza Mareta \\
\hline 36 & 201801036 & Elsi \\
\hline 37 & 201801092 & Rezki Maryani \\
\hline 38 & 201801100 & Rizlah Ambarzah \\
\hline 39 & 201901058 & Mutiara \\
\hline 40 & 201901059 & Intan Ulandari \\
\hline 41 & 202001041 & Muhammad Rozi \\
\hline 42 & 202001053 & Rani Anjastari \\
\hline 43 & 201701023 & Muhlisin \\
\hline 44 & 201701009 & Dian Tri Utami \\
\hline 45 & 201801029 & Dewi Septiana \\
\hline 46 & $201701007 \mathrm{P}$ & Dewi Lucyana Aryani \\
\hline 47 & 201701008 & Diah Ayu Purwanti \\
\hline 48 & 201701010 & Dwi Anggun Julianti \\
\hline 49 & 201701024 & Muhtar Pido \\
\hline 50 & 201701025 & Nanda Sulistya Wati \\
\hline 51 & $201801149 \mathrm{P}$ & Fadhilah Amirullah \\
\hline 52 & 202001027 & Putri Allia Ramdhani \\
\hline 53 & 202001050 & M. Rahman Arif Pranata \\
\hline 54 & 202001051 & Khoirul Addha \\
\hline 55 & 202001052 & Muhammad Abdhu Ridho \\
\hline 56 & 201701001 & Ade Guntur \\
\hline 57 & 201701002 & Afid Afendi \\
\hline 58 & 201701017 & Jihan Fahira \\
\hline 59 & $201701044 \mathrm{P}$ & Welly Rinaldy \\
\hline
\end{tabular}


ISLAMIC BANKING: Jurnal Pemikiran dan Pengembangan Perbankan Syariah, Volume 7 Nomor 1 Edisi Agustus 2021

\begin{tabular}{|c|c|c|}
\hline 60 & $201701045 \mathrm{P}$ & Bunga Aprilia \\
\hline 61 & 201801152 & Muhammad Iqbal \\
\hline 62 & 201801178 & Nurbaiti \\
\hline 63 & $201801179 \mathrm{P}$ & M. Fazal Rizvi \\
\hline 64 & 201801180P & Zuleha \\
\hline 65 & 201901073 & Rindhu Adji Pramana \\
\hline 66 & $201901081 \mathrm{P}$ & Erdian \\
\hline 67 & 202001044 & Haikal Izzaya \\
\hline 68 & 202001045 & Muhammad Anshorullah \\
\hline 69 & 202001046 & Rio Salsa Julian \\
\hline 70 & 202001047 & Muhammad Thoriq \\
\hline 71 & 201701033 & Shinta Dewi Putri \\
\hline 72 & 201801102 & Rohimin \\
\hline 73 & 201601018 & Siti Indah Lestari \\
\hline 74 & 201701026 & Nia Agustriana \\
\hline 75 & 201701035 & Siti Hartina \\
\hline 76 & 201801130 & Vira Maulidia \\
\hline 77 & 202001042 & Reza Putra Pratama \\
\hline 78 & 202001043 & Hasyir Afqori \\
\hline 79 & 202001054 & Sindi Permatasari \\
\hline 80 & 201901004 & Rafli Ilham Dhani \\
\hline 81 & 201901010 & Cindi Adela \\
\hline 82 & 201901012 & Aziladia Ratna \\
\hline 83 & 201901014 & Anggih Rahmawati Antoni \\
\hline 84 & 201901027 & M. Youga Agung.G \\
\hline 85 & 201901028 & Putri Milasari \\
\hline 86 & 201901030 & Noni Hutami \\
\hline 87 & 201901033 & Bella Aulia \\
\hline 88 & 201901036 & Aldo Juliansyah \\
\hline 89 & 202001055 & Widia Purnama Sari \\
\hline 90 & 201702021 & Sukma Yulani \\
\hline 91 & 201802029 & Indah Ayu Luthfiana \\
\hline 92 & 201802032 & Ipang Supriyono \\
\hline 93 & 201802033 & Kgs. M. Rendy Septian S \\
\hline 94 & 201902025 & Firda Zuraika Putri \\
\hline 95 & 201902032 & Apriliani \\
\hline 96 & 201702015 & Lilis Anggraini \\
\hline 97 & 201802082 & Yulia Citra \\
\hline 98 & 201702001 & Ahmad Ichsan \\
\hline 99 & 201802002 & Afifah Ghoida \\
\hline 100 & 201802008 & Ayu Nariski \\
\hline 101 & -201902067 & Sayyid Umary \\
\hline 102 & 201902065 & Indrianti \\
\hline
\end{tabular}


100 Fadilla, Meika Puspita Sari, DAMPAK COVID 19 TERHADAP SISTEM PEMBELAJARAN ......

\begin{tabular}{|c|c|c|}
\hline 103 & $\mid 202002013$ & Arisyah \\
\hline
\end{tabular}

Dari 486 Mahasiswa total mahasiswa STEBIS IGM dimana jumlah mahasiswa ekonomi 308 dan Program Studi Perbankan Syariah 173. Ada 103 Mahasiswa yang tidak mampu membayar UKT. Artinya 30\% mahasiwa STEBIS IGM tidak mampu membayar UKT pada masa Pandemi Covid 19. Dampak sosial juga terjadi pada masa Pandemi Covid 19 yaitu pembatasan sosial berskala besar (PSBB) yang menyebabkan mahasiswa tidak dapat melakukan perkuliahan secara tatap muka. Oleh sebab itu kampus melakukan perkuliahan secara online sesuai dengan anjuaran pemerintah.

Pandemi Covid 19 juga dirasakan oleh para dosen dan karyawan di STEBIS IGM. Dosen tidak diwajibkan datang ke kampus kecuali yang memiliki tugas tambahan seperti Kaprodi, Kepala Bagian, maupun Kepala Seksi. Adapun bagian administrasi harus tetap datang ke kampus, namun kedatangan dosen yang memiliki tugas tambahan dan administrasi ini mulai dari hari senin sampai jumat. Ini menyebabkan berkurangnya honor transport dosen dan karyawan. Berdasarkan latar belakang di atas peneliti ini melakukan penelitian dengan judul penelitian Dampak Covid 19 Terhadap Pendidikan dan Ekonomi di STEBIS IGM.

\section{Rumusan Masalah}

Berdasarkan latar belakang yang peneliti ungkapan di atas maka rumusan penelitian dalam penelitian ini adalah :

1) Bagaimana sistem pembayaran UKT di STEBIS IGM pada masa Pandemi Covid 19 ?

2) Bagaimana dampak covid 19 terhadap pembayaran UKT Mahasiswa STEBIS IGM?

3) Bagaimana Sistem Perkuliahan mahasiswa STEBIS IGM ?

4) Bagaimana dampak covid 19 terhadap sistem perkuliahan Mahasiswa STEBIS IGM?

\section{Tujuan Penelitian}


ISLAMIC BANKING: Jurnal Pemikiran dan Pengembangan Perbankan Syariah, Volume 7 Nomor 1 Edisi Agustus 2021

Berdasarkan rumusan masalah dan latar belakang di atas maka tujuan dari penelitian ini adalah :

1) Untuk mengetahui sistem pembayaran UKT di STEBIS IGM pada masa Pandemi Covid 19

2) Untuk mengetahui dampak covid 19 terhadap pembayaran UKT Mahasiswa STEBIS IGM

3) Untuk mengetahui Sistem Perkuliahan mahasiswa STEBIS IGM

4) Untuk mengetahui dampak covid 19 terhadap sistem perkuliahan Mahasiswa STEBIS IGM

\section{Landasan Teori}

\section{Covid 19}

Penamanaan CoVid-19 dari World Health Organization (WHO) untuk coronavirus disease that was discoverd in 2019 pada tanggal 11 Februari 2020, dengan sebutan Covid-19 (Sarip, dkk 2020, Mukharom \& Aravik, 2020)) . Virus Corona (Corona Virus Diseases) adalah keluarga besar virus yang menyebabkan penyakit ringan sampai berat, seperti common cold atau pilek dan penyakit yang serius seperti MERS dan SARS . (Noer, dkk, $2020: 61$ )

Covid 19 merupakan penyakit baru yang memiliki tingkat penularan relatif cepat dan dapat menyebabkan kematian. oleh sebab itu, virus Covid 19 tidak dapat dianggap penyakit yang sepele meskipun pada tahun 1960, virus Covid 19 ini dianggap sebagai penyebab flu biasa (Al-Osail \& Al-Wazzah, 2017) (Harirah dan Anas, 2020 : 37)

Ciri-ciri yang dialami orang yang terkena Covid 19 antara lain :

1) Menurunnya daya tahan tubuh secara signifikan

2) Tidak mampunya penderita untuk merasakan rasa makannan

3) Batuk

4) Hilangnya kemampuan untuk mencium

\section{Dampak Dari Covid 19}


Covid 19 telah menimbulkan beberapa masalah dalam kehidupam masyarakat di dunia termasuk di Indonesia. Beberapa literatur dan hasil dari penelitian membuktikan bahwa banyak sekali dampak yang terjadi akibat covid 19 ini terutama dampak sosial. Covid 19 telah menyebabkan social distancing dan pemerintah beberapa waktu yang telah menerapkan aturan PSBB (Pembatasan Sosial Berskala Besar). Masyarakat dihimbau untuk selalau menjaga jarak serta selalu menggunakan masker ketika keluar rumah. Pada saat bulan Ramadhan tahun 2020 dikeluarkan himbauan untuk tidak memunaikan sholat tarawih dan sholat ied di masjid pada daerah yang teridentifikasi Zona Merah.

Dalam segi ekonomi banyak covid 19 ini telah memberikan dampak yang cukup signifikan juga. Sejak adanya covid 19 banyaknya perusahaan yang gulung tikar karena tidak mampu bertahan di era Pandemi ini salah satunya adalah Toko Ramayana yang terletak di Palembang. Banyak juga dari perusahaan yang membuat karyawannya di rumahkan karena tidak mampu membayar gaji karyawan. Perumbuhan ekonomi mengalami kelesuan akibat covid 19 ini.

Covid 19 ini juga berdampak pada dunia pendidikan kita. Mentri Pendidikan Indonesia Bapak Nadien Karim telah menerapkan aturan melarang murid-murid melakukan pembelaajran secara tatap muka dari tingkat Taman Kanak-kanan (TK) sampai Perguruan Tinggi (PT). Pembelajaran dilakukan secara daring/ online menggunakan via Zoom, goole meet, whats upp dan media lain yang tersedia.

\section{Penelitian Terdahulu}

Nor, dkk melakukan penelitian yang berjudul Analisis Dampak Covid-19 Terhadap Sosial Ekonomi Pedagang di Pasar Klaten dan Wonogiri. Hasil yang diperoleh menunjukkan bahwa dengan adanya pandemi virus Covid-19 ini perekonomian mengalami penurunan terutama pada pedagang pasar yang mengalami penurunan omzet dan penghasilan sebesar $50 \%$.

Sarif, dkk (2020) melakukan penelitian yang berjudul Dampak Covid-19 Terhadap Perekonomian Masyarakat dan Pembangunan Desa. Hasil penelitiannya menunjukkan bahwa Pandangan masyarakar desa telah mengalami krisis kepercayaan 
ISLAMIC BANKING: Jurnal Pemikiran dan Pengembangan Perbankan Syariah, Volume 7 Nomor 1 Edisi Agustus 2021

karena peran yang dimainkan pemerintah pusat dan daerah yang kurang memperhatikan desa sebagai pemerintahan mandiri kehilangan identitasnya.

Sina (2020) melakukan penelitian dengan judul Ekonomi Rumah Tangga di Era Pandemi Covid 19. Hasil penelitiannya menunjukkan bahwa Menghadapi tekanan ekonomi yang berat, ekonomi sector rumah tangga masih memiliki peluang bertahan dan dapat meningkatkan taraf hidupnya yaitu melalui ketepatan manajemen keuangan rumah tangga, berbagai pelatihan peningkatan skill baru dan disiplin dalam melaksanakan protokol kesehatan.

Herliandry (dkk) Melakukan sebuah penelitia yang berjudul Pembelajaran Pada Masa Pandemi Covid-19. Hasil penelitiannnya menunjukkan bahwa Pembelajaran online menjadi solusi efektif untuk mengaktifkan kelas meski sekolah yang telah ditutup mengingat waktu dan tempat menjadi beresiko pada masa pandemi ini. Namun, teknik pembelajaran ini penting untuk dievaluasi sesuai dengan kondisi setempat mengingat sebaran fasilitas dan kemampuan orang tua memberikan fasilitas pembelajaran online berbeda kepada peserta didik di Indonesia.

Aji (2020) meneliti sebuah penelitian yang berjudul Dampak Covid-19 pada Pendidikan di Indonesia: Sekolah, Keterampilan, dan Proses Pembelajaran. Penelitiannya menemukan bahwa Gangguan dalam proses belajar langsung antara siswa dan guru dan pembatalan penilaian belajar berdampak pada psikologis anak didik dan menurunnya kualitas keterampilan murid. Beban itu merupakan tanggung jawab semua elemen pendidikan khususnya negara dalam memfasilitasi kelangsungan sekolah bagi semua steakholders pendidikan guna melakukan pembelajaran jarak jauh. Bagaimana mestinya Indonesia merencanakan, mempersiapkan, dan mengatasi pemulihan covid 19, untuk menekan kerugian dunia pendidikan di masa mendatang.

Rusiadi (dkk) Melakukan penelitian yang berjudul Dampak Covid 19 Terhadap Stablititas Ekonomi Dunia (Studi 14 Negara Berdampak Paling Parah). Berdasarkan laporan Bank Indonesia diketahui bahwa hingga tanggal 29 Februari 2020, jumlah kasus infeksi COVID-19 tercatat sebanyak 85.207 kasus dengan kematian 2.924 orang. COVID19 sendiri telah tersebar di 60 negara. Adapun negara lain selain Tiongkok 
104 Fadilla, Meika Puspita Sari, DAMPAK COUID 19 TERHADAP SISTEM PEMBELAJARAN ......

$(93,01 \%)$ yang mengalami dampak cukup besar adalah Korea Selatan $(3,44 \%)$, Italia $(1,04 \%)$, Jepang $(1,10 \%)$ dan Iran $0,46 \%$.

\section{Metodologi Penelitian}

\section{Populasi dan sampel}

Populasi adalah seluruh objek yang akan ada di dalam penelitian. Objek dalam penelitian ini adalah Seluruh Civitas Akademika STEBIS IGM yang meliputi Dosen, staff karyawan dan mahasiswa di STEBIS IGM. Adapun sampel penelitian adalah Kepala Seksi Bagian Akademik, Kepala Bagian Umum, Kaprodi Perbankan Syariah dan Ekonomi Syariah, Ketua STEBIS IGM dan para mahasiswa khususnya yang mengalami masalah dalam pembayaran UKT (Uang kuliah tunggal).

\section{Teknik Analisis data}

Penelitian ini mengguankana data primer. Data primer merupakan data yang didapatkan langsung dari informan atau yang menjadi narsumber. Narasumber dalam penelitian ini adalah civitas akademika STEBIS IGM meliputi pemangku jabatan, dosen dan mahasiswa. Penelitian ini merupakan penelitian kualitatif. Penelitian kualitatif berfokus pada latar secara alamiah dengan maksud menerjemahkan fenomena yang terjadi (Moleong, 2009). Data yang dikumpulkan berdasarkan hasil wawancara dan observasi kepada mahasiswa maupun dosen.

\section{Pembahasan}

\section{Dampak Covid Terhadap Ekonomi Pada Civitas Akademika STEBIS IGM}

Pada masa Pandemi Covid 19 banyak mahasiswa STEBIS IGM yang menunggak pembayaran UKT. Berikut ini merupakan data dari beberapa mahasiswa STEBIS IGM yang tterlambat mengisis KRS dikarenakan belum melunasi pembayaran UKT

Tabel 2

Data Mahasiswa STEBIS IGM yang terlambat Pembayaran UKT

\begin{tabular}{|l|l|l|}
\hline No & NPM & Nama Mahasiswa \\
\hline 1 & 201801063 & M. Reza Fahlefi \\
\hline 2 & 201801069 & Meinur Aulia \\
\hline 3 & 201801070 & Meliari Ramadhon \\
\hline
\end{tabular}


ISLAMIC BANKING: Jurnal Pemikiran dan Pengembangan Perbankan Syariah, Volume 7 Nomor 1 Edisi Agustus 2021

\begin{tabular}{|c|c|c|}
\hline 4 & $201801160 \mathrm{P}$ & Yayan \\
\hline 5 & $201801162 \mathrm{P}$ & Muhammad Fathul Barie \\
\hline 6 & 201801176 & Jhoty Rizky Midia \\
\hline 7 & 201901047 & Dandy Pratama \\
\hline 8 & 201901078 & Jhodi Alpayed \\
\hline 9 & $201901084 \mathrm{P}$ & Sakroni \\
\hline 10 & 202001048 & Herli \\
\hline 11 & 202001049 & Muhammad Iqbal \\
\hline 12 & 201802025 & Fitriani \\
\hline 13 & 201902021 & Ernita \\
\hline 14 & 201902022 & Kintan Nurul Adiffah \\
\hline 15 & 202002016 & Diansari \\
\hline 16 & 201801058 & M. Alamsyah Harahap \\
\hline 17 & 201701021 & Memi Martalia \\
\hline 18 & 201701006 & Despa Leni \\
\hline 19 & 201701034 & Shinta Tri Lestari \\
\hline 20 & 201701036 & Slamet Abdul Aziz \\
\hline 21 & 201701040 & Wina Windari \\
\hline 22 & 201801115 & Siti Fatimah \\
\hline 23 & 201801123 & Suryani \\
\hline 24 & 201801173 & Rachmat Hastono Putra \\
\hline 25 & 201901068 & Satria Anugrah \\
\hline 26 & 201901070 & Mira Afriyanti \\
\hline 27 & 202001019P & M. Al Kausar \\
\hline 28 & 202001038 & Rahayu Widodo \\
\hline 29 & 202001039 & Kgs. M. Abdus Samad Al Palembani \\
\hline 30 & 202001040 & M. Malik Fajar \\
\hline 31 & 202001056 & Nesya Salma Waafi \\
\hline 32 & 201702008 & Dwi Septi Ningsih \\
\hline 33 & 201802041 & Mutiara \\
\hline 34 & 202002019 & Ade Restamia Putri \\
\hline 35 & 201701012 & Eriza Mareta \\
\hline 36 & 201801036 & Elsi \\
\hline 37 & 201801092 & Rezki Maryani \\
\hline 38 & 201801100 & Rizlah Ambarzah \\
\hline 39 & 201901058 & Mutiara \\
\hline 40 & 201901059 & Intan Ulandari \\
\hline 41 & 202001041 & Muhammad Rozi \\
\hline 42 & 202001053 & Rani Anjastari \\
\hline 43 & 201701023 & Muhlisin \\
\hline 44 & 201701009 & Dian Tri Utami \\
\hline 45 & 201801029 & Dewi Septiana \\
\hline 46 & $201701007 \mathrm{P}$ & Dewi Lucyana Aryani \\
\hline
\end{tabular}


106 Fadilla, Meika Puspita Sari, DAMPAK COVID 19 TERHADAP SISTEM PEMBELAJARAN ......

\begin{tabular}{|l|l|l|}
47 & 201701008 & Diah Ayu Purwanti \\
\hline 48 & 201701010 & Dwi Anggun Julianti \\
\hline 49 & 201701024 & Muhtar Pido \\
\hline 50 & 201701025 & Nanda Sulistya Wati \\
\hline 51 & $201801149 \mathrm{P}$ & Fadhilah Amirullah \\
\hline 52 & 202001027 & Putri Allia Ramdhani \\
\hline 53 & 202001050 & M. Rahman Arif Pranata \\
\hline 54 & 202001051 & Khoirul Addha \\
\hline 55 & 202001052 & Muhammad Abdhu Ridho \\
\hline 56 & 201701001 & Ade Guntur \\
\hline 57 & 201701002 & Afid Afendi \\
\hline 58 & 201701017 & Jihan Fahira \\
\hline 59 & $201701044 \mathrm{P}$ & Welly Rinaldy \\
\hline 60 & $201701045 \mathrm{P}$ & Bunga Aprilia \\
\hline 61 & 201801152 & Muhammad Iqbal \\
\hline 62 & 201801178 & Nurbaiti \\
\hline 63 & $201801179 \mathrm{P}$ & M. Fazal Rizvi \\
\hline 64 & $201801180 \mathrm{P}$ & Zuleha \\
\hline 65 & 201901073 & Rindhu Adji Pramana \\
\hline 66 & $201901081 \mathrm{P}$ & Erdian \\
\hline 67 & 202001044 & Haikal Izzaya \\
\hline 68 & 202001045 & Muhammad Anshorullah \\
\hline 69 & 202001046 & Rio Salsa Julian \\
\hline 70 & 202001047 & Muhammad Thoriq \\
\hline 71 & 201701033 & Shinta Dewi Putri \\
\hline 72 & 201801102 & Rohimin \\
\hline 73 & 201601018 & Siti Indah Lestari \\
\hline 74 & 201701026 & Nia Agustriana \\
\hline 75 & 201701035 & Siti Hartina \\
\hline 76 & 201801130 & Vira Maulidia \\
\hline 77 & 202001042 & Reza Putra Pratama \\
\hline 78 & 202001043 & Hasyir Afqori \\
\hline 79 & 202001054 & Sindi Permatasari \\
\hline 80 & 201901004 & Rafli Ilham Dhani \\
\hline 81 & 201901010 & Cindi Adela \\
\hline 82 & 201901012 & Aziladia Ratna \\
\hline 83 & 201901014 & Anggih Rahmawati Antoni \\
\hline 84 & 201901027 & M. Youga Agung .G \\
\hline 85 & 201901028 & Putri Milasari \\
\hline 86 & 201901030 & Noni Hutami \\
\hline 87 & 201901033 & Bella Aulia \\
\hline 88 & 201901036 & Aldo Juliansyah \\
\hline 89 & 202001055 & Widia Purnama Sari \\
\hline 90 & 201702021 & Sukma Yulani \\
\hline & & \\
\hline
\end{tabular}


ISLAMIC BANKING: Jurnal Pemikiran dan Pengembangan Perbankan Syariah, Volume 7 Nomor 1 Edisi Agustus 2021

\begin{tabular}{|l|l|l|}
91 & 201802029 & Indah Ayu Luthfiana \\
\hline 92 & 201802032 & Ipang Supriyono \\
\hline 93 & 201802033 & Kgs. M. Rendy Septian S \\
\hline 94 & 201902025 & Firda Zuraika Putri \\
\hline 95 & 201902032 & Apriliani \\
\hline 96 & 201702015 & Lilis Anggraini \\
\hline 97 & 201802082 & Yulia Citra \\
\hline 98 & 201702001 & Ahmad Ichsan \\
\hline 99 & 201802002 & Afifah Ghoida \\
\hline 100 & 201802008 & Ayu Nariski \\
\hline 101 & -201902067 & Sayyid Umary \\
\hline 102 & 201902065 & Indrianti \\
\hline 103 & 202002013 & Arisyah \\
\hline
\end{tabular}

Sumber : Bagian Akademik STEBIS IGM

Berdasarkan wawancara dengan salah satu mahasiswa perbankan Afifah ghoidah dan Indrianti mereka tidak dapat melakukan pembayaran UKT dikarenakan orang tua mereka dirumahkan sehingga tidak dapat membayar UKT tepat waktu. Dari beberapa mahasiswa tersebut ada juga yang bekerja dan kehilangan pekerjaannya oleh sebab itu mereka tidak memiliki penghasilan untuk membayar UKT mahasiswa tersebut antara lain : Jhoty Rizki dari Prodi Ekonomi Syariah, Fitriani dari prodi Perbankan Syariah. Berdasarkan hasil wawancara dengan mereka, mereka menyampaikan semenjak Covid 19 mereka di PHK (Pemutusan Hubungan Kerja) oleh atasan tempat mereka bekerja karena omset penjualan menurun. Disisi lain bagi lembaga STEBIS IGM Covid 19 menyebabkan sedikitnya penerimaan mahasiswa baru baik dari Prodi Perbankan Syariah maupun dari prodi Ekonomi Syariah.

Pada tahun 2019 tercatat bahwa jumlah mahasiswa baru di STEBIS IGM mencapai 155 orang namun 2020 jumlah mahasiswa baru di STEBIS IGM mengalami penurunan menjaadi 70 orang. Keadaan ini jelas berdampak pada sumber pendapatan di STEBIS IGM, dimana selama ini Sumber pemasukan berasal dari UKT dan pendaftaran mahasiswa baru. Sedikitnya yang mendaftar sebagai mahasiswa baru menyebabkan kurangnya pendapatan bagi dosen. Berkurangnya pendapatan ini karena sedikitnya jam mengajar dosen. Semakin banyak kelas yang diajar maka semakin banyak juga SKS mengajar dosen. Jika dosen banyak mengajar honor dosen juga akan semakin banyak sebaliknya Semakin sedikit kelas yang diajar maka semakin sedikit juga SKS mengajar 
dosen. Selain itu ada karyawan dipindahkan dari bagian yang satu ke bagian yang lain, untuk menghemat biaya gaji di STEBIS IGM.

Semenjak Covid 19 STEBIS IGM menambah jumlah kapasitas internet dan WIFI. Hal ini tentu menimbulkan biaya tambahan. Sejak dikeluarkan peraturan Mentri pendidikan yang melarang untuk melakukan kuliah secara tatap muka, maka mau tidak mau STEBIS IGM harus menambah biaya jaringan internet, karena diperlukan internet yang stabil dan lancar ketika dosen menjelaskan perkuliahan melalui vidio ataupun Zoom.

\section{Kebijakan STEBIS IGM dalam Menghadapi Masalah Keuangan Semenjak Covid 19}

Semenjak Covid 19 yayasan IGM yang meliputi UIGM, STEBIS IGM, SMA LTI IGM, SMP LTI IGM, SD Plus IGM, dan TK IGM menghimbau penghematan penggunaan listrik untuk menekan biaya operasional yang ada mengingay pembelajaaan dilakukan secara daring. STEBIS IGM mengikuti himbauan yayasan tersebut dengan mengingarkan kepada OB yaitu Mas Bajuri dan Mbak Marida untuk selalu mematikan AC dan lampu setelah selesai membersihkan kelas serta tidak menghidupkannya selama ruangan tersebut tidak diguanakan untuk rapat maupun bimbingan skripsi.

STEBIS IGM atas persetujuan Yayasan IGM juga memberikan kesempatan kepada mahasiswa yang kesulitan melakukan pembayaran dengan memberikan kesempatan mencicil uang UKT. Mahasiswa yang mau mencicil pembayaran UKT harus membuat surat perjanjian yang ditanda tangani oleh mahasisw, wali siswa dan Kaprodi. Berikut ini merupakan contoh surat perjanjiaan mahasiswa untuk melakukan pembayarn UKT secara mencicil. 
ISLAMIC BANKING: Jurnal Pemikiran dan Pengembangan Perbankan Syariah, Volume 7 Nomor 1 Edisi Agustus 2021

\section{Gambar 1 \\ Contoh Surat Perjanjian Pembayaran Cicilan Mahasiswa}

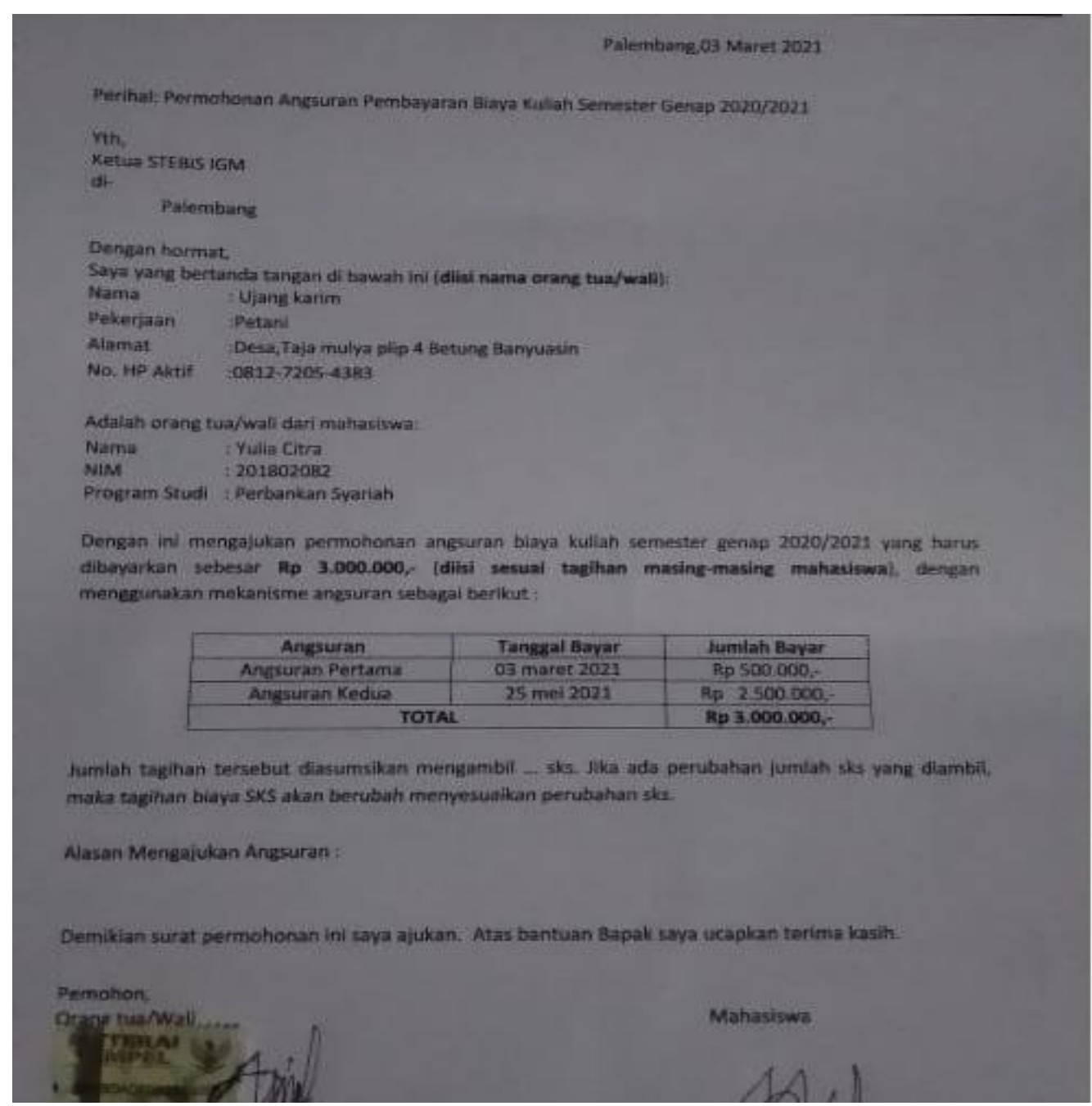

Dari Gambar 1 di atas dapat kita ketahui bahwa mahasiswa atas nama Yulia Citra mencicil sebanyak 2 kali yaitu anggusan pertama sebanyak Rp. 500.000. dan angsuran kedua sebanyak Rp. 2500.000. Surat Perjanjian tersebut ditanda tangani oleh mahasiswa dan orang tua wali menanda tangani surat perjanjiannya diatas materai. Setelah itu disetujui oleh Ketua STEBIS IGM

\section{Dampak Covid 19 Terhadap Sistem Pembelajaran di STEBIS IGM}

Sejak covid mahasiswa melakukan pembalajaran secara daring melalui siakad pada sistem siakad ini tersinkronisasi dengan edllink. Pada edlnik ada kolom absen, 
komentar penguploadtan vidio pembelajaran dan rung diskusi atau zoom dengan kapasitas waktu 40 menit.

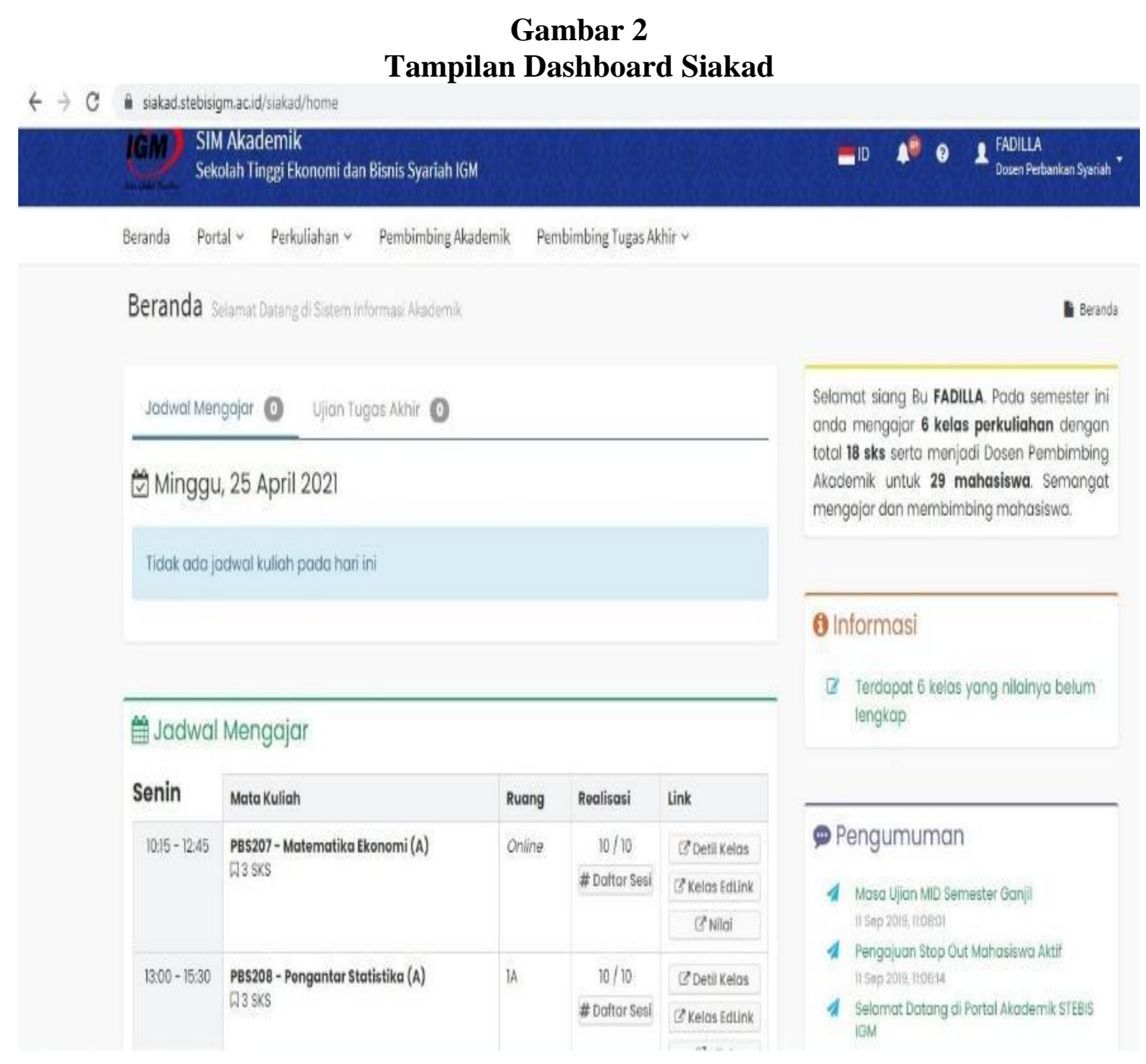

Dari tampilan dashboard siakad tersebut terdapat menu perkuliahan dimana padda menu tersebut setiap dosen dapat mengetahui mereka mengajar Mata kuliah apa saja, pada hari dan siapa saja peserta perkuliahan. Selain itu ada menu pembimbing akademik dan pembimbing tugas akhir, dengan begitu setiap dosen mengetahui perkembangan mahasiswa yang dimana mereka menjadi walinya dan dosen dapat memantau nilai perkuliahan dan mata kuliah apa saja yang diambil oleh anak PA nya. Dalam proses perkuliahan pelaksanaan kuliah online dilakukan dengan menggunakan sistem edlink. 
ISLAMIC BANKING: Jurnal Pemikiran dan Pengembangan Perbankan Syariah, Volume 7 Nomor 1 Edisi Agustus 2021

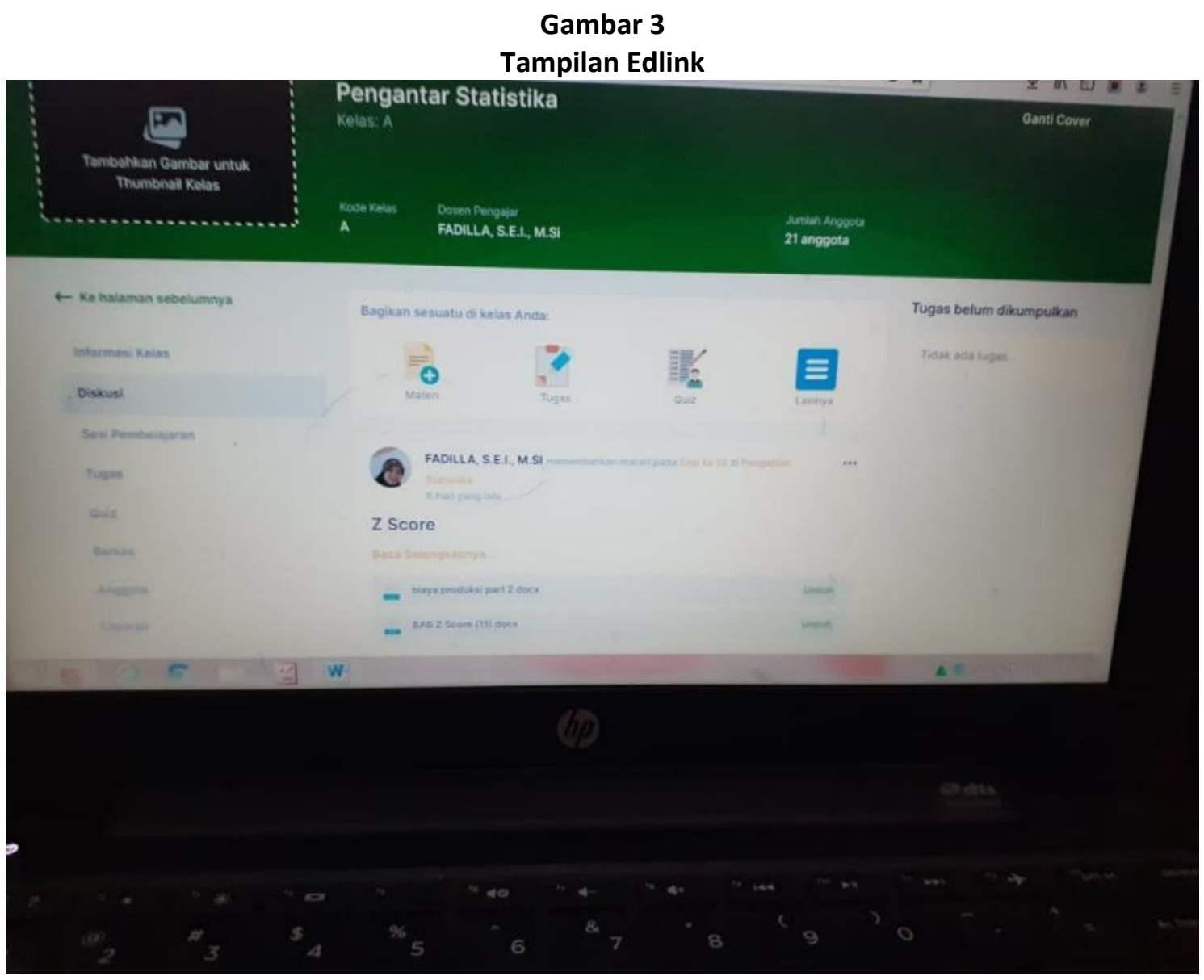

Pada Dushboard tampilan edlink tersebut pada sebelah kiri ada menu sesi pembelajaran dimana menu ini setiap perkuliahan dimulai dosen dapat membuka peetemuannya dengan mngklik sesi pertemua dan menambahkan pertemuan sesuai dengan jadwal perkuliahan itu sendiri. Pada bagian atas edlink terlihat ada gambar materi, menu ini akan di klik oleh dosen ketika mereka akan memberikan materi pelajarannya kepada mahasiswa. Menu tugas di berikan oleh dosen ketika akan memberikan tugas pada mahasiswa. Menu quiz akan dibuka dosen ketika dosen akan memberikan ujian ataupun Quiz pada mahasiswanya. Dosen juga dapat melakukan teleconference kepada mahaiaswa melalui Zoom yang juga telah disediakan di sistem edlink ini. 
112 Fadilla, Meika Puspita Sari, DAMPAK COVID 19 TERHADAP SISTEM PEMBELAJARAN ......

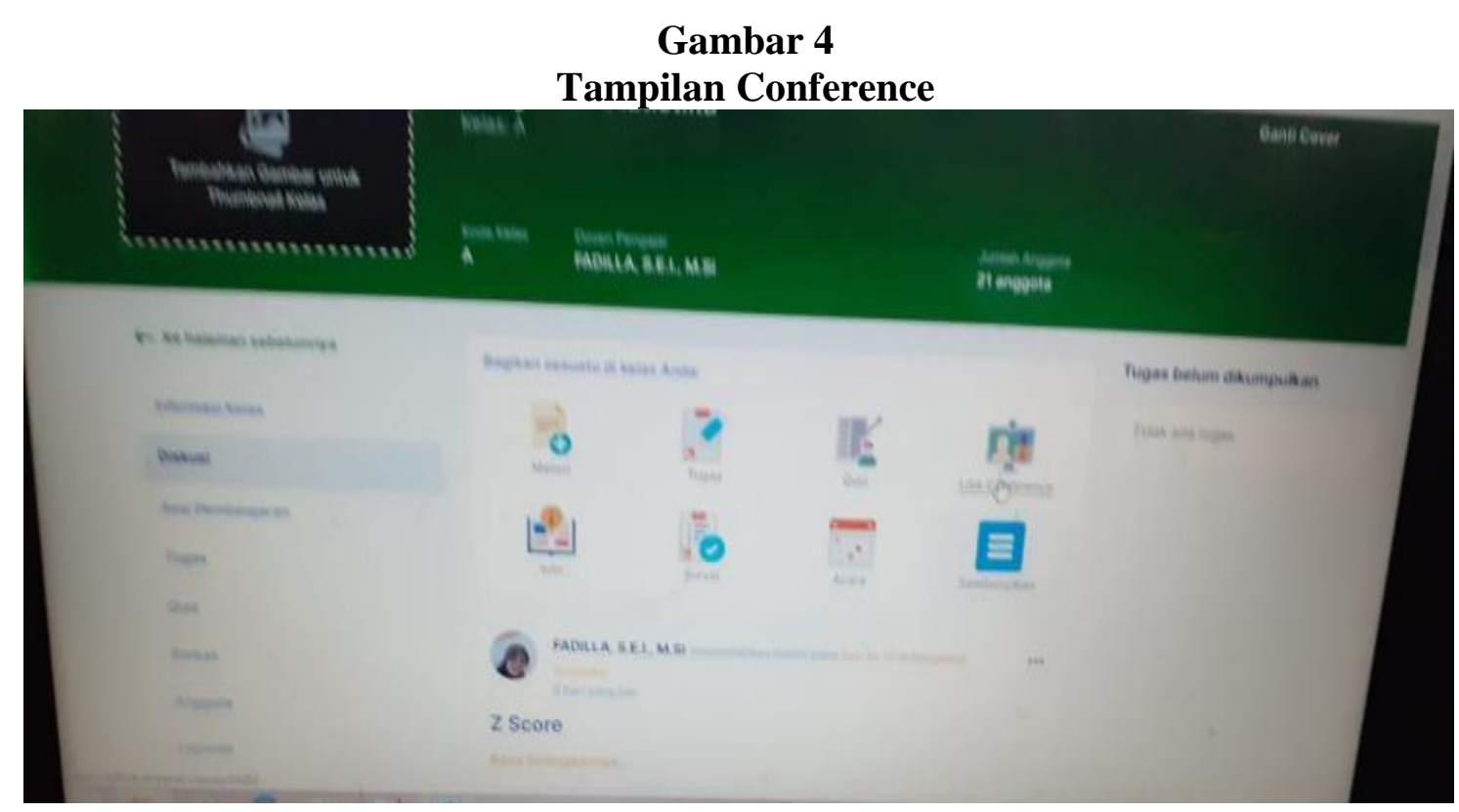

Pada gambar diatas terdapat menu life conference, menu ini akan digunakan jika dosen ingin melakukan conference. Biasanya kebanyakan dosen melakukannya pada saat akan melakukan diskusi secara langsung dengan mahasiswa. Dosen dapat mengetahui hadir tidaknya mahasiswa dengan melihat apakah mahasiswanya masuk pada menu edlink atau tidak seperti tampilan di bawah ini.

\section{Gambar 5}

Tampilan Absen Mahasiswa di Edlink

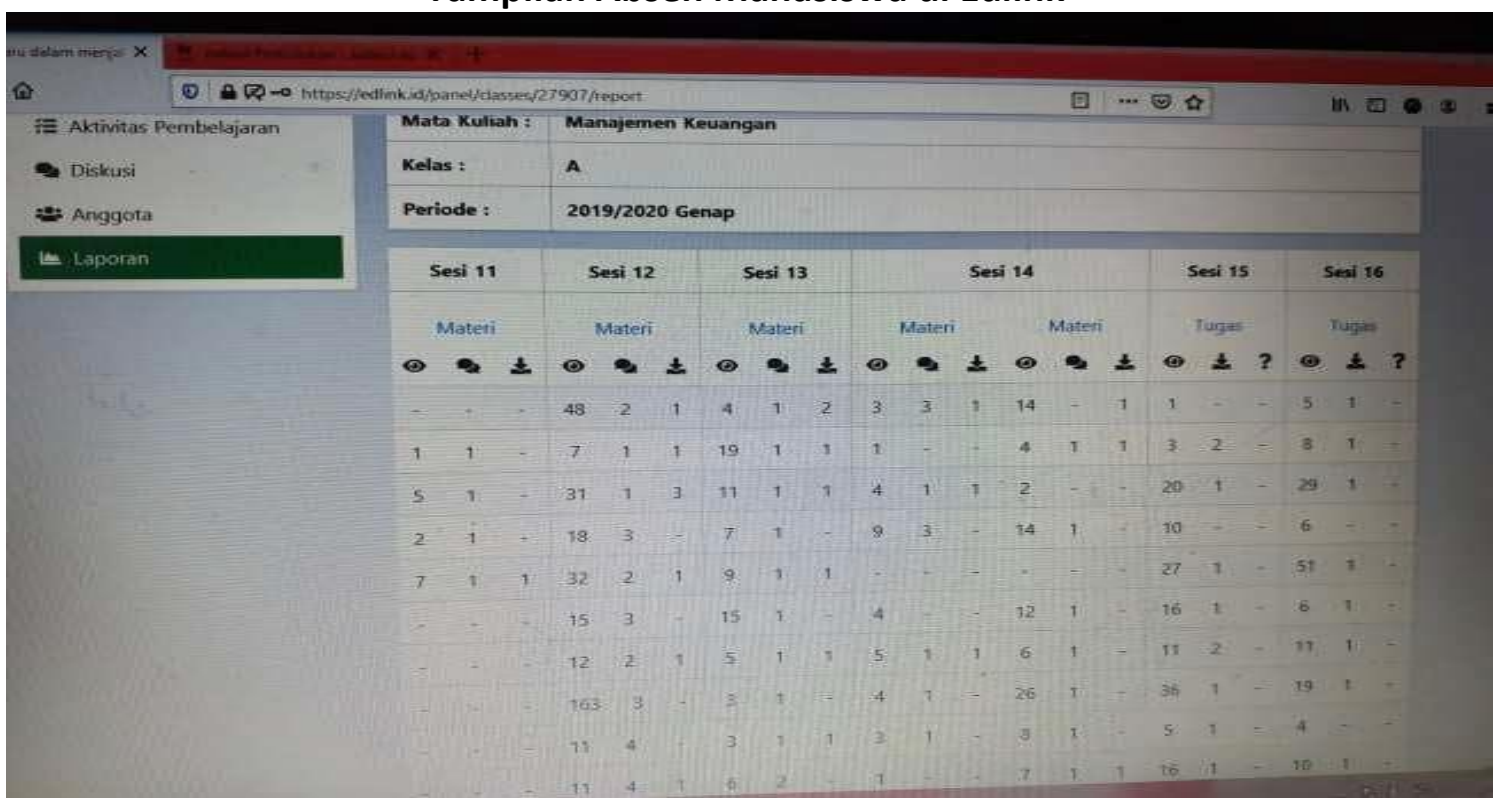


Meskipun Sarana serta sistem pembelajaran online telah diseiapkan oleh STEBIS IGM dengan baik namun kenyataanya masih banyak keluhan atau kedala-kendala pada saat melangsungkan perkuliahan secara online ini. Berdasarkan wawancara dengan dosen dan mahasiswa STEBIS IGM banyak kendala dan keluhan yang dialami oleh mereka. Keluhan tersebut meliputi:

1) Jaringan yang tidak stabil

2) Dosen sulit memonitor mahasiswanya satu persatu

3) Mahasiswa menjadi segan mengikuti zoom mengingat sedikitnya waktu buat bertanya dan belaja

4) Mata Kuliah praktikum sulit dijelaskan jika tidak melalui tatap muka

\section{Simpulan}

Covid 19 telah memberikan dampak negatif dari segi kehidupan termasuk dalam dunia pendidikan, hal ini tidak terlepas dari Universitas termasuk Sekolah Tinggi ekonomi dan Bisnis Syariah (STEBIS) IGM. Penelitian ini meneliti tentang dampak Covid 19 dalam bidang ekonomi dan pembelajaran.

Covid 19 menyebabkan mahasiswa STEBIS IGM tidak dapat membayar UKT (Uang Kuliah Tunggal) secara tepat waktu karena banyak orang tua dari mahasiswa kehilangan pekerjaannya dan mahasiswa yang bekerja juga telah tidak dapat membayar UKT karena telah dirumahkan. $30 \%$ mahasiswa STEBIS IGM tidak dapat membayar UKT. Untuk mengaktisipasinya maka STEBIS IGM memberikan kesempatan sebanyak 2 (dua) kali pembayaran UKT bagi mahasiswa yang tidak mampu.

Covid 19 menyebabkan pembelajaran di STEBIS IGM juga berubah dari Luring (tatap muka) menjadi Daring (online). Untuk memperlancar pembelajaran secara daring STEBIS IGM telah dibantu dengan menggunakan sistem akademik secara online yaitu SIAKAD dan Edlink. Dosen dapat mengirimkan materi, tugas bahkan melakukan teleconference melalui sistem edlink ini. Ada beberapa hambatan dalam sistem pembelajaran secara online. (1) Jaringan yang tidak stabil. (2)Dosen sulit memonitor mahasiswanya satu persatu, (3) Mahasiswa menjadi segan mengikuti zoom mengingat 
sedikitnya waktu buat bertanya dan belajar 4)Mata Kuliah praktikum sulit dijelaskan jika tidak melalui tatap muka

\section{DAFTAR PUSTAKA}

Harirah, Zulfah dan Anas Rizaldi. 2020. Merespon Nalar Kebijakan Negara Dalam Menangani Pandemi Covid 19 di Indonesia. Jurnal Ekonomi dan Kebijakan Publik Indonesia Vol. 7 No. 1

Herliandry, Luth Devi, Nurhasannah, Maria Enjelina Suban, Heru Kuswanto.2020. Pembelajaran Pada Masa Pandemi Covid-19. Jurnal Teknologi Pendidikan. Vol. 22, No. 1

Mukharom, M., \& Aravik, H. (2020). Kebijakan Nabi Muhammad Saw Menangani Wabah Penyakit Menular dan Implementasinya dalam Konteks Penanggulangan Coronavirus Covid-19. SALAM: Jurnal Sosial Dan Budaya Syar-I, 7(3). https://doi.org/10.15408/sjsbs.v7i3.15096

Nor, Rizki Azima, Ismi Nur khasanah, Rizki Pratama, Zulfanissa Azizah, Wahyu Febrianto, Shafa Rifdha Syafira Purnomo. 2020. Analisis Dampak Covid 19 Terhadap Sosial Ekonomi Pedagang di Pasar Klaten Wonogiri. Jurnal Ilmu Kesejahteraan Sosial (EMPATI) Vol.9 No.1

Sarip, Aip Syarifudin dan Abdul Muaz.2020. Dampak Covid 19 Terhadap Perekonomian Masyarakat dan Pembangunan Desa. Jurnal Al-Mustashfa Vol.5 No.1

Sina, Peter Gerlans. 2020. Ekonomi Rumah Tangga di Era Pandemi Covid-19. Journal Of Management (SME's) Vol. 12 No.2

Tobing, Wirman dan Mohd. Riczy Azummy. 2020. Hubungan Covid 19 Terhadap Sektor Pendidikan, Ekonomi dan Pertanian (Ekologi) di Indonesia. Jurnal Syntax Admiration Vol.1 No.5 